九州大学学術情報リポジトリ

Kyushu University Institutional Repository

A new insight into oceanography with multivariate and time-series analyses on the 1990-1999 planktonic foraminiferal fluxes in the Bering Sea and the central subarctic Pacific

Asahi, Hirofumi

Ocean Research Institute, University of Tokyo

Takahashi, Kozo

Department of Earth and Planetary Sciences, Graduate School of Sciences, Kyushu University

https://doi.org/10.5109/11808

出版情報: 九州大学大学院理学研究院紀要 : Series D, Earth and planetary sciences. 32 (1)， pp.73-96, 2008-02-01. Faculty of Science, Kyushu University

バージョン :

権利関係 : 
Mem. Fac. Sci., Kyushu Univ., Ser. D, Earth \& Planet. Sci., Vol. XXXII, No. 1, pp. 73-96, February 1, 2008

\title{
A new insight into oceanography with multivariate and time-series analyses on the 1990-1999 planktonic foraminiferal fluxes in the Bering Sea and the central subarctic Pacific
}

\author{
Hirofumi Asahi* and Kozo Takahashi**
}

\begin{abstract}
A nine year-long study on planktonic foraminifer fluxes was conducted in the Bering Sea (Station $\mathrm{AB}$ ) and the central subarctic Pacific (Station SA). Mathematical analyses were carried out in order to decipher the consequences of temporal variation of foraminifer fluxes and their faunal assemblages with the oceanographic variability. As a result of R-mode (true) factor analysis, four factors were recognized: Warm Water Factor; Seasonal Factor; Temperature Factor; and Oligotrophic Factor. The temporal variations of these four factors appeared to correspond to the oceanographic changes occurred at each of the stations. Among the temperature-related factors, Temperature Factor showed reasonable correlation coefficients with SST anomaly at both stations (Station AB: $r=0.57$; Station SA: $r=0.83$ ). Notable high scores of Warm Water Factor occurred during 1997 at Station SA. During this period, a significant suppression of the other measured biogenic particles such as diatoms occurred. This extraordinary event observed at Station SA may be a reflection of the large scale climatic shift. The temporal variation of Oligotrophic Factor at each of the stations demonstrated different oceanographic features which controlled the local primary production. At hemipelagic Station AB, the temporal variation of the SST anomaly, which is a measure of controlling the subsurface nutrient supply to surface layer, was the significant feature influential to the local primary production. On the other hand, the power balance between the Alaskan Stream and the Subarctic Current influenced most to the local primary production at pelagic Station SA. The Maximum Entropy Method revealed that temporal variation of foraminifer fluxes, their relative abundances, and the factor scores fluctuated with significant periodicity. Most fluxes of foraminifer taxa at Stations AB and SA showed significant seasonal (six month, and twelve month-long) and inter-annual (twenty to forty month-long) cycles. Seasonal cycles were attributed to the occurrence of the primary flux maxima, which occurred in fall (Station $\mathrm{AB}$ ) and spring (Station $\mathrm{SA}$ ), and the secondary maxima appeared in spring (Station $\mathrm{AB}$ ) and fall (Station $\mathrm{SA}$ ). The periodicities of the relative abundances were the most significant for the twelve month-long cycle. The nine year-long monthly means of the relative abundances and their twelve month-long cycles
\end{abstract}

Manuscript received on 2 November 2007; accepted on 27 November 2007

* Ocean Research Institute, University of Tokyo

1-15-1 Minamidai Nakano-ku Tokyo 164-8639, JAPAN;

** Department of Earth and Planetary Sciences, Graduate School of Sciences, Kyushu University

Hakozaki 6-10-1, Higashi-ku Fukuoka 812-8581, JAPAN;

e-mail: hiroasa@ori.u-tokyo.ac.jpo 
indicated the preference of each of the foraminiferal taxa in a specific condition. Contrary, the periodicity of four factors tended to appear inter-annually, except for Seasonal Factor. It was the only factor with twelve month-long cycle. The other factors appeared to have twenty to forty month-long cycles. The inter-annual cycle of these factors may be a reflection of the large scale climatic shift occurred in the Bering Sea and the subarctic Pacific during 1990 to 1999.

Keywords: long-term time series, R-mode true factor analysis, Bering Sea, planktonic foraminifers, annual variation, inter-annual variation, MEM spectrum analysis

\section{Introduction}

The Bering Sea and the central subarctic Pacific belong one of the most biologically productive regions in the world. This region is with a characteristic of the high biological production with high contribution by the siliceous shell-bearing plankton such as diatoms and radiolarians (Takahashi et al., 2000, 2002). Together with the Okhotsk Sea, the Bering Sea is a marginal sea with a high production by diatoms (Takahashi, 1998). However, there have been little understandings for ecology of calcareous plankton such as planktonic foraminifers and coccolithophores in this region.

Among these biogenic particles, planktonic foraminifers have been focused upon reconstructing paleoceanograhic conditions because of their responses to a variety of oceanographic features. Imbrie and Kipp (1971) introduced a multivariate analysis (Q-mode Principal component Analysis) to reconstruct paleo-temperature using transfer functions derived by sea surface temperature data and planktonic foraminiferal assemblages from surface sediments.

Food availability, depth of mix layers and temperature are considered as controlling factors to their productions and faunal assemblages. Laboratory culturing of planktonic foraminifers showed that each of the taxa has certain optimum temperature and salinity for their growth (e.g., Bijima et al., 1990). Several studies by plankton tows and sediment traps have indicated that production of planktonic foraminifers and their faunal assemblages are controlled by food supply (e.g., Watkins et al., 1996; Mohiuddin et al., 2002; Eguchi et al., 2003), temperature and thermal structure of the water column (e.g., Schiebel et al., 2001; Shr?der-Rirzrau et al., 2001; King and Howard, 2003).

Temperature and thermal structure of the water column are considered the controlling factors of planktonic foraminifer production and their faunal assemblages. First described by Murray (1897), variations of their faunal assemblages are well reflecting along latitudinal zones, which correlate those of sea surface temperatures. Zaric et al. (2006) have noted that production of several species including Neogloboquadrina pachyderma and Globigerina quinqueloba reflects the significant influences of sea surface temperatures. Furthermore, several studies conducted in the Nordic Sea (Koheld et al., 1996; Corstens et al., 1997) and the Antarctic Ocean (Donnar and Wefer, 1994) has indicated the preferences of a surbarctic fauna $N$. pachyderma in the relatively warm water.

In order to decipher the relation between planktonic foraminifers and the oceanographic changes, several taxon quantitative studies have been performed upon planktonic foraminifer fluxes in the subarctic Pacific (e.g., Sauter and Thunell, 1986; Eguchi et al., 1999; Kuroyanagi et al., 2002). Their works noted that the foraminifer fluxes and their faunal assemblages clearly corresponded to the oceanographic changes such as food availability and temperature in the subarctic Pacific. However, their works mainly focused on the temporal variation of the relative abundances of foraminiferal faunal assemblages and their fluxes along the oceanographic changes. Since faunal assemblages of these plankton reflects oceanographic environment with many factors (e.g., temperature and food availability), it is difficult to examine their relationship by simply comparing temporal variation of each 
fauna with environmental factors. The advantage of multivariable analysis is to yield a small number o underlying factors. Therefore, the mathematical application to the results of taxon-quantitative works with environmental factors has a key to decipher not only general information on biological system but also the ecology of planktonic foraminifers itself.

In this study, we employed the mathematical analysis on the taxon quantitative results of the nine year-long time-series planktonic foraminifers at Station AB and Station SA. Using the results obtained from these invaluably long time-series samples, we evaluate the correspondence of the planktonic foraminifer fluxes and their faunal assemblages with the oceanographic changes.

\section{Oceanographic settings}

The Bering Sea and the central subarctic Pacific are characterized by the high biological production attributed to high diatom production (Takahashi et al., 2000, 2002). Geographically, the Bering Sea is connected to the Chukchi Sea in the Arctic Ocean, and hence it consequently plays an important role in water mass exchange between the Pacific Ocean and the Atlantic Ocean (Takahashi, 1999). In this region, a variation of sea surface temperature (SST) can be considered as one of the most significant oceanographic features. A significant variation of SST influences physiochemical and biological conditions in the surface layers. Based upon the satellite images, the SST ranged from 2 to $10^{\circ} \mathrm{C}$ at Station $\mathrm{AB}$ whereas at Station SA SST ranged from 4 to $12^{\circ} \mathrm{C}$ (Reynolds and Smith, 1994). A strong seasonal thermocline appears around at $20 \mathrm{~m}$ (Station AB) and $15 \mathrm{~m}$ depth (Station SA), respectively, during the summer period when the surface layer was heated around 7 to $12^{\circ} \mathrm{C}$ due to high solar radiation. On the other hand, the strong thermocline deepens to $150 \mathrm{~m}$ (Station $\mathrm{AB}$ ) and $90 \mathrm{~m}$ depth (Station SA) during the late winter period of cold SST attributed to the radiative heat loss to the atmosphere (Levitus and Boyer, 1994).

The surface circulation in this region is another oceanographic feature to bring the variation in the physiochemical and biological conditions (Nagata et al., 1992). Because of the unique geography, Stations AB and SA are under influence of the different surface circulations, respectively. Station AB is located in the Bering Sea which is considered as a semi-closed marginal sea with hemipelagic conditions whereas Station SA in the subarctic Pacific is considered as in the open pelagic realm. In the Bering Sea, the Bering Gyre is the most dominant surface flow in the semi-closed hemipelagic realm. On the other hand, the Alaskan Stream and the Subarctic Current are the two significant flows at Station SA. Since Station SA is located in an open ocean, the water mass exchanges due to these two flows are expected. The Alaskan Stream is a westward flow originating from the Alaskan Gyre in the Gulf of Alaska, whereas the Subarctic Current flows eastward originating from the Western Subarctic Gyre, running along the south of the Alaskan Stream. These two currents running around Station SA reflect characters of gyres where they are originally running from. In the Western Subarctic Gyre, the annual SST is two to three degrees lower than that in the Alaskan Gyre (Dodimead, 1967; Dodimead and Pickard, 1967). The other difference of the two gyres can be described as the differences in primary plankton producers. Harrison et al. (2004) discussed their differences from a point of nutrient profiles and phytoplankton dynamics. They have indicated lower calcifications (mainly produced by coccolith and planktonic foraminifers) and higher diatom productions in the Western Subarctic Gyre than in the Alaskan Gyre. From these facts discussed above, waters in the Alaskan Stream can be described as relatively warm and low diatom production compare to that in the Subarctic Current. It has been reported that these two currents change their paths attributing to their strength intra-annually and inter-annually (Ohnishi and Ohtani, 1999; Ohnishi, 2000). 


\section{Methods}

\subsection{Planktonic foraminifer analysis}

Consecutive nine year-long particle flux samples were collected during 1990 to 1999 by two sediment traps (PARFLUX Mark 7G-13 with 13 rotary collectors; Honjo and Doherty, 1988) moored in the Bering Sea (Station AB: $53^{\circ} 30 \mathrm{~N}, 177^{\circ} \mathrm{W}$, sea- floor depth: $3788 \mathrm{~m}$, trap depth: 3198 $\mathrm{m}$ ) and the central subarctic Pacific (Station SA: $49^{\circ} \mathrm{N}, 174^{\circ} \mathrm{W}$, sea- floor depth: $5406 \mathrm{~m}$, trap depth: $4812 \mathrm{~m}$; Fig. 1). Each of the mooring systems was designed to set the collecting instruments at approximately $600 \mathrm{~m}$ above the sea-floor. Recoveries, maintenance, and redeployments of the traps were carried out every August on T/S Oshoro-maru of the Hokkaido University, Japan. Most of the sampled intervals were set for 20 or 56 days (for exact information on the sampled schedules, see Takahashi et al., 2002). Prior to the deployment, each of the trap cups were filled with deep sea water collected at $2000 \mathrm{~m}$ depth of the respective stations. In order to preserve the sedimentary biological materials collected, the deep water was mixed with either glutaraldehyde (1990-1994) or formaldehyde (1995-1999) to make up 5\% solution, which was sodium borate-buffered (pH 7.67.8).

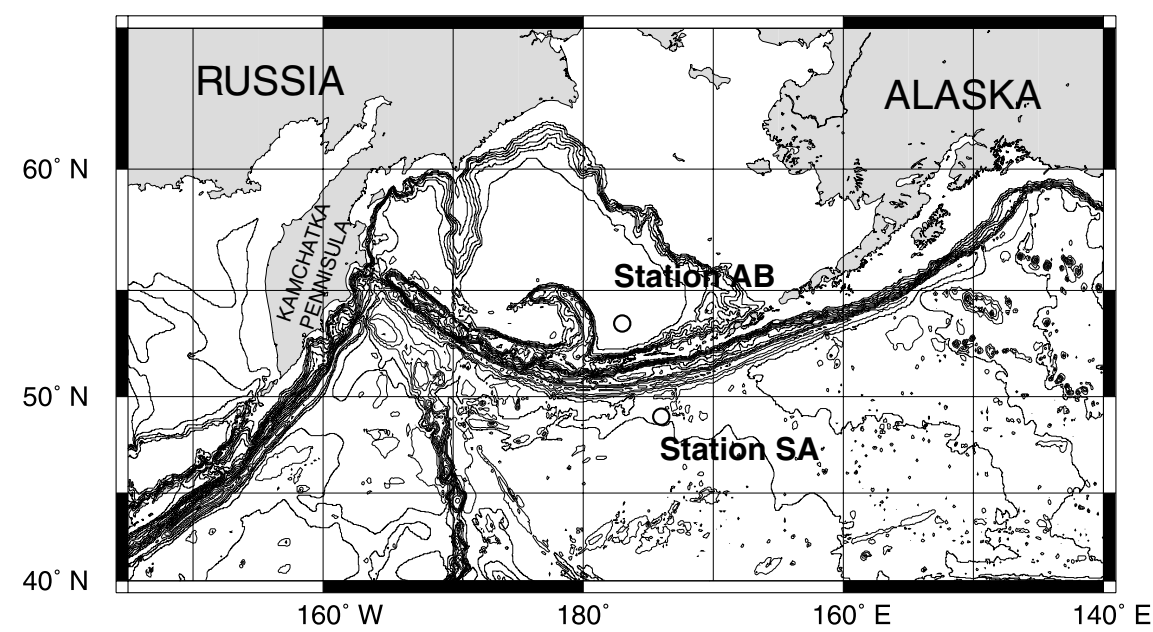

Fig. 1. Map showing the deployed locations of the long-term time-series sediment traps: Station AB in the Aleutian Basin of the Bering Sea and Station SA in the central subarctic Pacific.

On board at dock, recovered trap samples were wet-sieved through $1 \mathrm{~mm}$ stainless sieve to remove the large crustaceans. The sample of $<1 \mathrm{~mm}$ was split into four sub-samples with a rotary splitter. In the shore laboratory, samples were again split into sub-samples whose aliquot size ranged from $1 / 16$ to $1 / 16384$, depending upon purposes of further analysis. For this work, 1/64 aliquot size was chosen. After the splitting, all samples were sieved through $500 \mu \mathrm{m}, 250 \mu \mathrm{m}, 125 \mu \mathrm{m}$, and 63 $\mu \mathrm{m}$ stainless steel meshes and thus five size fractions were obtained: 1000-500 $\mu \mathrm{m}, 500-250 \mu \mathrm{m}$, 250-125 $\mu \mathrm{m}, 125-63 \mu \mathrm{m}$, and 63-0 $\mu \mathrm{m}$. Since the shell size of adult planktonic foraminifers ranged 
from $125 \mu \mathrm{m}$ upward, three size fractions greater than $125 \mu \mathrm{m}$ were focused in this investigation. All samples greater than $125 \mu \mathrm{m}$ were examined under a dissecting microscope for counting and species identification. The counted foraminifer data were converted to fluxes (No. shells $\mathrm{m}^{-2} \mathrm{~d}^{-1}$ : Appendix Table 1).

\subsection{Mathematical calculation (factor analysis and spectrum analysis)}

With the obtained nine year-long time-series of foraminifer faunal assemblages, R-mode varimax true factor analysis was applied to our data set. A factor analysis is the mathematical analysis which attempts to resolve the similarities between entities in terms of placement in a multidimensional space.

There are two common methods for this mathematical analysis, the "principal components" and "true factor analysis". Their differences mainly attribute to their way of defining factors. In principal component analysis, all of the factors are determined to account for maximum variance of subjective data sets, while those are calculated for maximum inter-correlations of all subjective variables (Reyment and Jöreskog, 1993). Among these methods, principal component analysis is a common method for scientific studies using factor analysis (including Imbrie and Kipp, 1971: They have applied Q-mode principal components analysis). This popularity mainly owes to its simple calculation process and its convenience in standard statistical software packages (e.g., SPSS and SAS). However, Costello and Osborne (2005) suggested their preference of true factor analysis to principal component analysis for extracting latent factors, because principal component analysis is only a data reduction method and it is computed without regard to any underlying structure in subjective data-sets. In our study, true factor analysis was employed, because the main goal of our study is "to reveal latent factors controlling faunal assemblages of planktonic foraminifers", but not to compile them (Asahi and Takahashi, 2007, for raw data see Apendix Table 1).

In order to perform this analysis, the relative abundances of foraminiferal faunal assemblages were calculated (Asahi and Takahashi, 2007). The samples, whose total counts of foraminifers were less than 100 specimens, were excluded prior to execution of this analysis. Following the method introduced by Reyment and Jöreskog (1993), an R-mode factor analysis with varimax rotation was carried out to our data set. All of the calculation procedures were performed by "Esumi ${ }^{\circledR}$ Excel addin package for multivariate analysis".

In order to understand the periodicities of foraminifer flux, their relative abundances, and Rmode true factors, we employed the Maximum Entropy Method (MEM: Burg, 1967). Our data set, whose sampled intervals were either 20 or 56 days, was standardized to equal intervals prior to the calculation. The MEM power spectrum was calculated by a software called AnalySeries 1.2 (Paillard et al., 1996).

\section{Results}

\section{1. Factor analysis}

The nine year-long time-series fluxes of planktonic foraminifers were observed at Stations AB and SA (Asahi and Takahashi, 2007). In order to grasp the general information on the changes in the foraminiferal faunal composition, an R-mode true factor analysis with varimax rotation was applied to the data set described above (Figs. 2-4; Appendix Table 1). The foraminifer flux at Stations AB and SA were mostly comprised by six taxa: Neogloboquadrina pachyderma, Globigerina umbilicata, Globigerinita glutinata, Globigerina quinqueloba, Orbulina universa, and Globorotalia wilesi, respectively. These six taxa occupied $99 \%$ of the foraminiferal faunal composition throughout the nine years at both stations (Asahi and Takahashi, 2007). The other unidentified foraminifers were counted as Other foraminifer spp. Their 


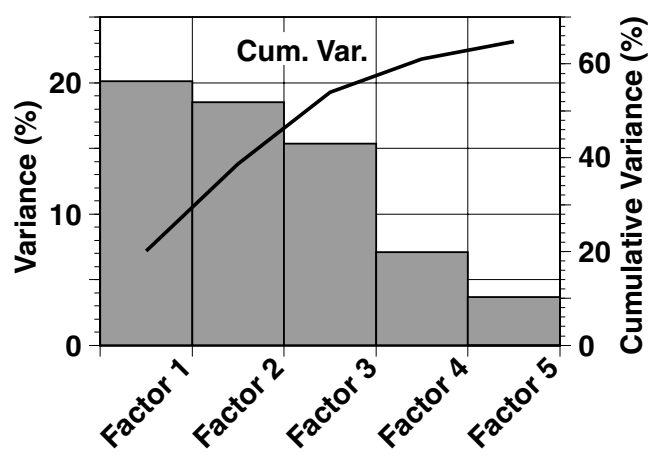

Fig. 2. The plots of the variances and their cumulative variances of the R-mode true factor analysis performed to the nine year-long time-series of foraminifer fluxes at Stations AB and SA.
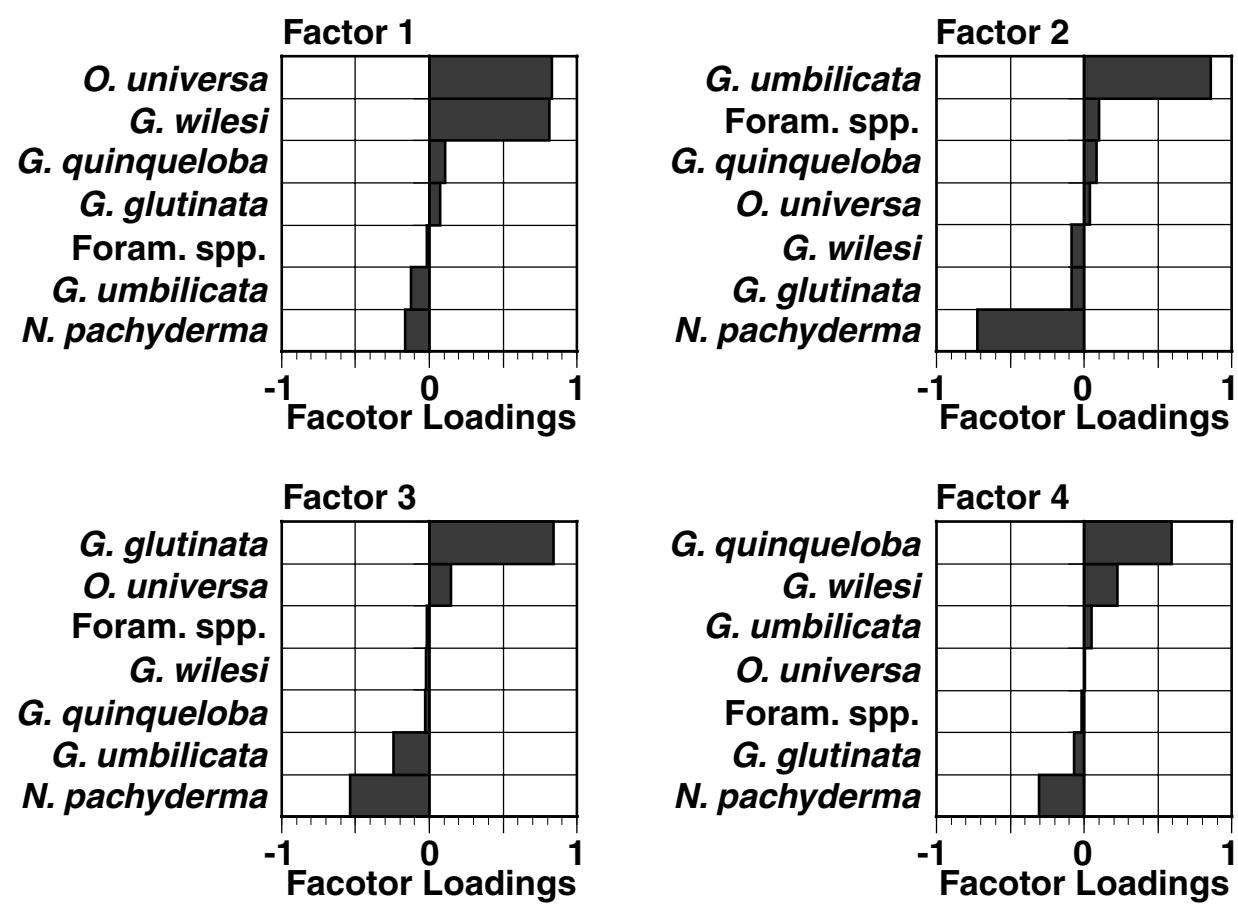

Fig. 3. The factor loadings of first four factors calculated by R-mode true factor analysis at Stations AB and SA. 


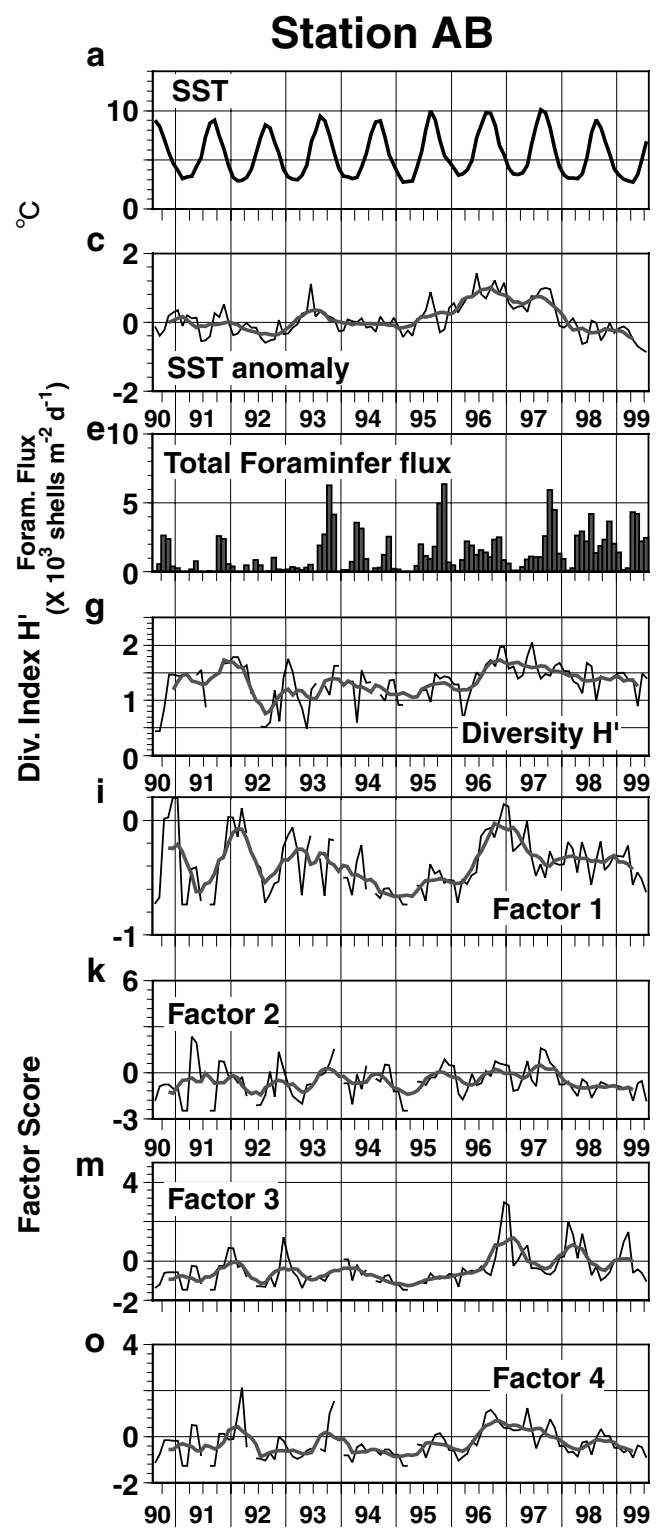

b

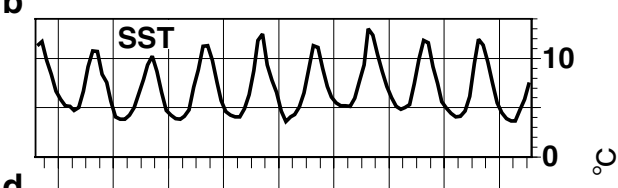

d

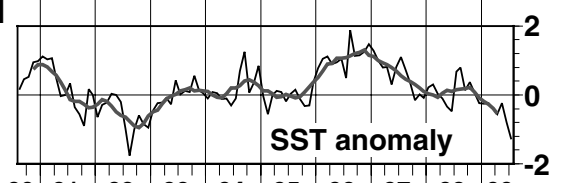

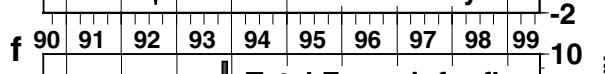

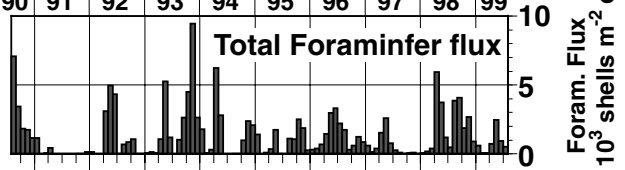

h

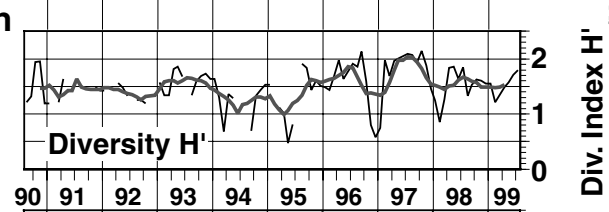

j

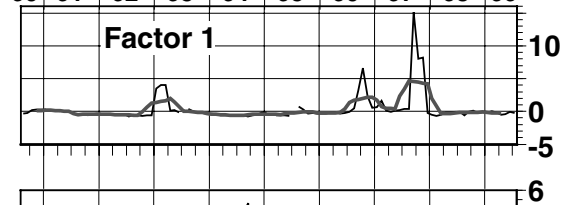

I

Factor 2

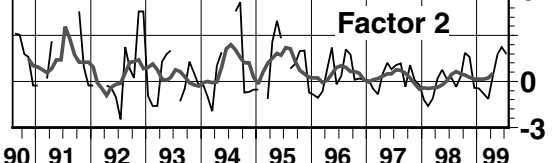

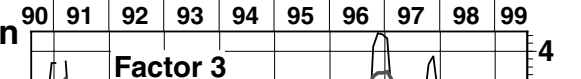
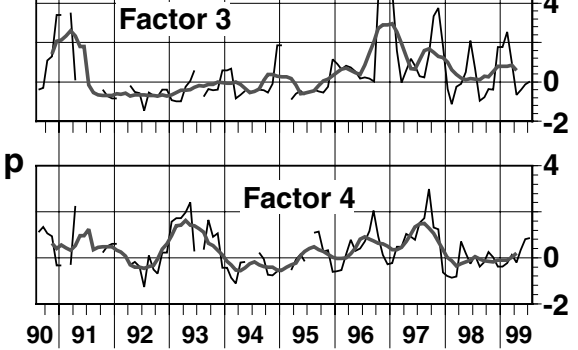

Fig. 4. The nine year-long time-series of SST (a, b), SST anomaly (c, d), total foraminifer flux (e, f), Shanon-Wiener diversity index (g, h), and first four R-mode true factors (i-p) at Stations AB and SA during 1990-1999. 
abundances were rare (mean: Station AB: $0.31 \%$; Station SA: $0.58 \%$ ), and thus the effect by these foraminifers were limited to the factor analysis.

As a result, we obtained five factors. Following other studies using factor analysis (e.g., Imbrie and Kipp, 1971), the use of Eigenvalues is one of the criteria for deciding numbers of factors to be retained. Majority of their studies use the Kaiser criterion (all factors greater than one) for their decisions. The true factor analysis tends to result in lower variances of factors and its eigenvalues than those by the principal component analysis due to its calculation procedure (Reyment and Jöreskog, 1993; Costello and Osborne, 2005). Application of Kaiser criterion does not always yield the best result. For our result, Factors 1 to 3 were suitable for this criterion (Table 1). The variance of these three factors ranged from 15 to $20 \%$. Furthermore, the cumulative variance of these three factors was $55 \%$ (Fig. 2). In order to obtain the detailed information on the foraminiferal faunal composition, we add Factor 4 to the further discussion. And therefore, the cumulative variance of the four factors reached $60 \%$ (Fig. 2).

Table 1. The R-mode true factor loading matrix and their variances calculated from nine year-long time series fluxes of foraminifer faunal assemblages at Stations AB and SA.

\begin{tabular}{rrrrr}
\hline & $\begin{array}{c}\text { Factor 1 } \\
\text { (Warm Water) }\end{array}$ & $\begin{array}{c}\text { Factor 2 } \\
\text { (Seasonal) }\end{array}$ & $\begin{array}{c}\text { Factor 3 } \\
\text { (Temperature) }\end{array}$ & $\begin{array}{c}\text { Factor 4 } \\
\text { (Oligotrophic) }\end{array}$ \\
\hline N. pachyderma & -0.16 & -0.72 & -0.54 & -0.30 \\
G. umbilicata & -0.12 & 0.86 & -0.24 & 0.05 \\
G. quinqueloba & 0.11 & 0.08 & -0.03 & 0.59 \\
G. glutinata & 0.07 & -0.09 & 0.84 & -0.07 \\
G. wilesi & 0.81 & -0.08 & -0.02 & 0.22 \\
O. universa & 0.83 & 0.04 & 0.15 & 0.00 \\
Variance & -0.02 & 0.10 & -0.02 & -0.02 \\
\hline
\end{tabular}

\subsubsection{Factor loadings and scores}

The R-mode true factor analysis of our data set showed a significant trend during 1990 to 1999. The factor loadings of Factor 1 were described by significantly positive loadings of Globorotalia wilesi and Orbulina universa (Fig. 3). The factor loadings of the other foraminifers were quite small, ranging from 0.2 to 0.2 . The nine year-long time-series of Factor 1 score showed notable maxima in 1993, 1996, and 1997 at Station SA, and the values increased ten times higher than the other period. Compared to Station $\mathrm{SA}$, the amplitude of Factor 1 score at Station $\mathrm{AB}$ was the tenth of that at Station SA. The factor loadings of Factor 2 were described by two taxa; positive loading by Globigerina umbilicata (0.8) and negative loading by Neogloboquadrina pachyderma (-0.7: Fig. 3). The factor loadings of the other taxa were quite small as Factor 1. The scores at Station SA showed higher values than that at Station AB during the study period. The significant maxima were visible at the end of 1992, and 1994 at Station SA. The loadings of Factor 3 were described by the positive values of Globigerinita glutinata and the negative values of $N$. pachyderma and G. umbilicata (Fig. 3). Their scores showed high values during 1990 to 1991 at Station SA and during 1996 to 1997 at both stations than the other years. The loadings of Factor 4 were defined by two taxa; N. pachyderma and G. quinqueloba (Fig. 3). The nine year-long of the scores showed periods with notable high values during 1993 at Station SA and 1996 to 1997 at both stations. 


\section{2. MEM}

In order to understand the periodicity of each data set the maximum entropy method (Burg, 1967) has been applied to our data set. Each subject data showed seasonal and inter-annual cycles.

\subsubsection{Foraminifer flux}

The MEM power spectrum of foraminifer fluxes showed conspicuous periodicities: six month, one year, and two year-long cycles (Fig. 5). The cycles within one year were more significant at Station AB than Station SA. These timings of the periodicity were observed in most of the foraminifer taxa except for Orbulina universa and Globorotalia wilesi, which consisted less than $0.1 \%$ throughout of the observed years. Among the foraminifer fluxes, the amplitude of the MEM power spectra of Globigerina umbilicata and Globigerina quinqueloba differed from that of the total foraminifer flux. The power spectra of these two taxa showed significantly high spectra in the one year-long cycle at Station AB.

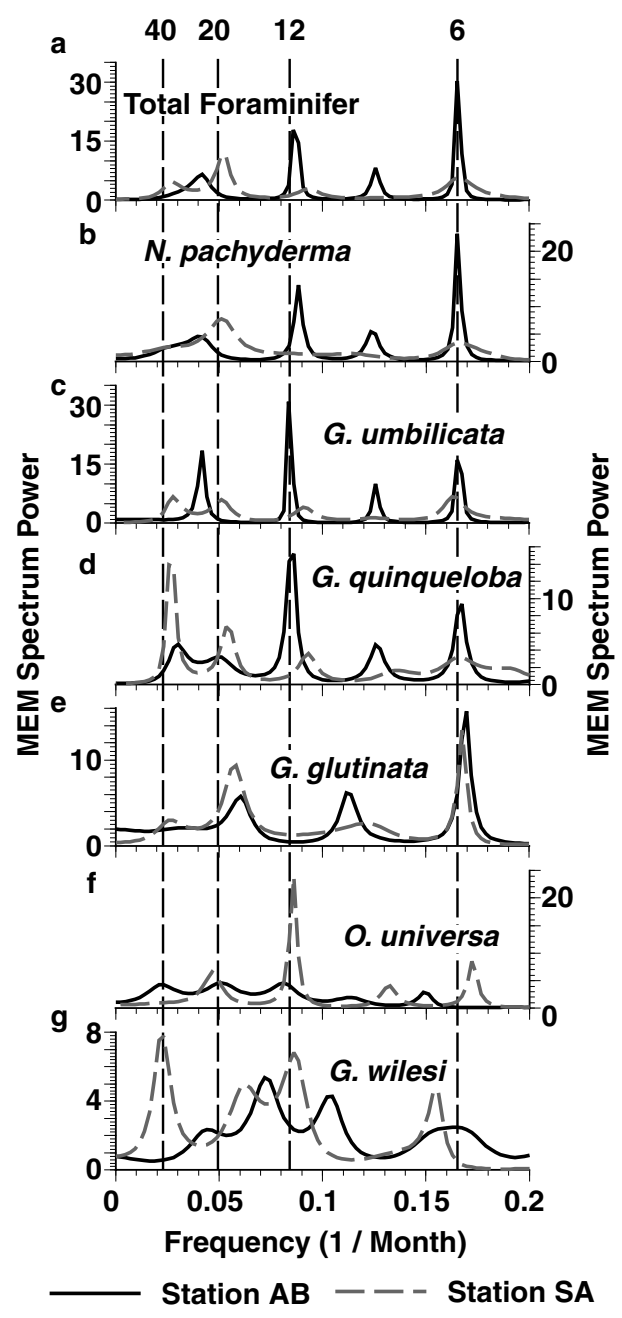

Fig. 5. The plots of frequency vs. the MEM power spectrum of total foraminifer flux (a) and fluxes of each of the foraminifer taxa (b-g) at Stations $\mathrm{AB}$ and $\mathrm{SA}$. 


\subsubsection{Faunal composition}

The periodicity of the relative abundances of each of the foraminifer taxa clearly represented annual and inter-annual variations (Fig. 6). The MEM power spectrum of Neogloboquadrina pachyderma, which was the most abundant taxon at both Stations $\mathrm{AB}$ and $\mathrm{SA}$, showed clear six month and three year-long cycles at both stations. Globigerina umbilicata and Globigerinita glutinata were the taxa that showed high annual cycle. The power spectrum of these taxa showed significant peaks at 0.08 to $0.09 \mathrm{~Hz}$. This frequency is referred to one year-long cycle. That periodicity of G. glutinata appeared at equal amplitude at both stations. That of G. umbilicata was more apparent at Station SA than Station AB. The MEM spectrum of Orbulina universa and Globorotalia wilesi showed peculiar cycles. Globorotalia wilesi showed an apparent twenty month-long cycle. The MEM power spectrum of $O$. universa showed three different peaks at each station; six month, one year, and twenty month-long at Station AB, and six month, one year-long, and forty month-long at Station SA.

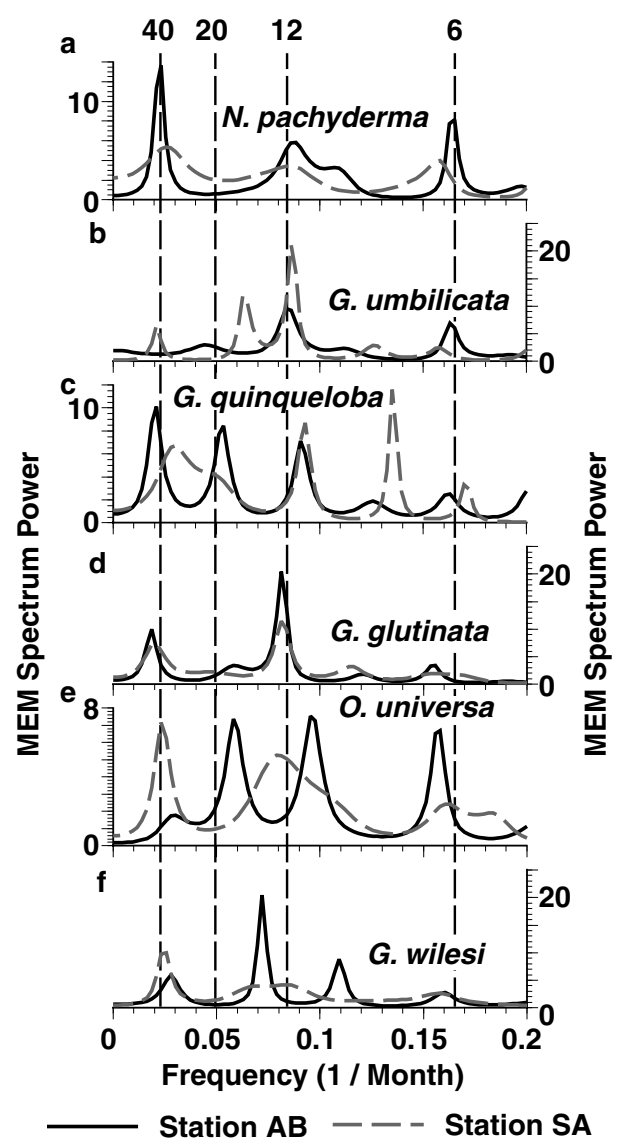

Fig. 6. The plots of frequency vs. the MEM power spectrum of the relative abundances of each of the foraminifer taxa at Stations $\mathrm{AB}$ and $\mathrm{SA}$. 


\subsubsection{Factors}

The MEM power spectrum of factors obtained by the factor analysis to foraminifer faunal assemblages showed significant inter-annual variations at both stations (Fig. 7). Factor 1 and Factor 3 showed conspicuous one year and forty month-long cycles at both studied stations. Though the periodicity of Factor 4 also appeared at one year and forty month-long at both stations, the forty month-long cycle at Station SA was not as clearly visible as that at Station AB. Factor 2 was the only factor whose seasonal periodicity was clearly legible. Especially, one year-long cycle was clearly visible at Station AB. Most of these visible cycles were more apparent at Station AB than those at Station SA.

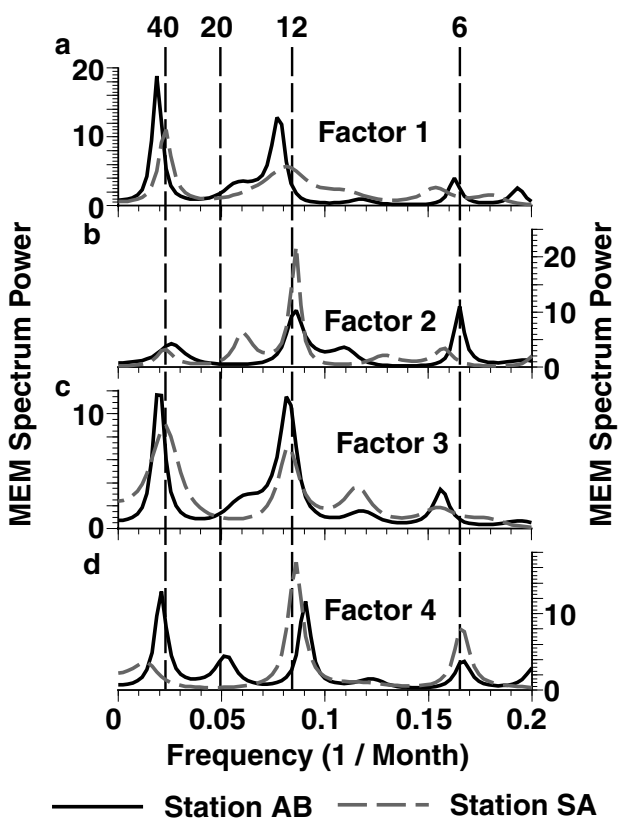

Fig. 7. The plots of frequency vs. the MEM power spectrum of R-mode varimax true factors at Stations AB and SA.

\section{Discussion}

\section{1. Factors}

\subsubsection{Definition of the each factor}

The factor scores obtained by the R-mode true factor analysis clearly represented the oceanographic changes at the study stations (Fig. 4). The each factor loading reflected the characteristic faunal compositions. The Factor 1 is defined as "Warm Water Taxon Factor" because of the large contributions by Orbulina universa and Globorotalia wilesi (Fig. 3). There have been many studies on O. universa, and there is a general agreement that this taxon prefers warm waters (e.g., Bé and Tolderlund, 1971; Thunell and Honjo, 1981). These two taxa appeared only in the limited periods at Stations AB and SA when the surface waters were warm (Asahi and Takahashi, 2007). Hence, this factor represented that the effect of the warm water mass occurred at each of the stations. 
Factor 2, the second contributing factor, was dominated by Globigerina umbilicata and Neogloboquadrina pachyderma (Fig. 3). These two taxa were the first and second dominant taxa, respectively, throughout the observed period at Stations $\mathrm{AB}$ and SA. The percent abundances of these two taxa were $83 \%$ at Station $\mathrm{AB}$ and $70 \%$ at Station SA. The seasonal variation of G. umbilicata appeared to have its maxima of the percent abundances during warm periods at Stations AB and SA (Asahi and Takahashi, 2007). Moreover, conspicuous one year-long cycle was clearly visible for this factor (Fig. 7). Hence, Factor 2 can be correlated with unsubtle variations in faunal assemblages and seasonal temperature changes. It is thus defined as the "Seasonal Factor".

The third factor is noteworthy to discuss, because of the positively high contribution by Globigerinita glutinata (Fig. 3). This taxon has a wide range of distribution from subtropical to polar regions (Bradshow, 1959). This widely distributed taxon is most likely to be found at tropical to subtropical realms. Globigerinita glutinata, however, also prefers upwelling environments (Bè and Tolderlund, 1971; Thunell and Reynolds, 1984). This notable habitat of this taxon was observed at the study stations. This taxon is unique because its percent abundances tended to show its maxima during winter period (Asahi and Takahashi, 2007). Moreover, the periodicity of $\% G$. glutinata is clearly visible for one year-long. Therefore, it can be said that their percent abundances reach their maxima every winter. Nevertheless, $\% G$. glutinata reached their maxima during winter, their percent abundance tended to show drastically high values during the period, while the sea surface temperature anomaly was positive (Asahi and Takahashi, 2007). Hence, it is reasonable to say that this factor is also correlated with the temperature changes. Hence, it is defined as "Temperature Factor".

The forth factor, is dominated by Globigerina quinqueloba (Fig. 3). It is worth to discuss this factor, when we argue this with the geographic distribution of this taxon. Globigerina quinqueloba was the one of the most abundant taxon in the other sediment trap studies in the subarctic Pacific (Station PAPA: Sauter and Thunell, 1989; Site 8: Eguchi et al., in prep; 50N: Kuroyanagi et al., 2002). Asahi and Takahashi (2007) pointed out its preference for relatively oligotrophic waters in the subarctic Pacific, because that the ranking trend in the mean $\%$. quinqueloba appeared as an opposite pattern to the trend of opal flux levels at all concerned stations. Furthermore, this taxon is known as harboring photosynthetic symbionts (Hemleben et al., 1989) and is reported to prefer to live in the well mixed water in the Santa Barbara Basin (Kincaid et al., 2000). It is now reasonable to characterize that this taxon prefers to live in the oligotrophic waters in the subarctic realms. Therefore, it is defined as "Oligotrophic Factor".

\subsubsection{Oceanographic changes impliedby the factors}

Nine year-long time-series of the R-mode true factor analysis scores showed a significant trend along the oceanographic changes at the study stations (Fig. 4). The definitions of each factors derived by the faunal information exhibited that most of R-mode true factors represented temperature-related entities such as "Warm Water Factor" (Factor 1), "Seasonal Factor" (Factor 2), and "Temperature Factor "(Factor 3).

Among these factors, the nine year-long variation of "Temperature Factor" (Factor 3) draws attention with the relation with temperature changes. The high correlation of this factor with temperature variation is apparent by the scatter plot of seven-month running means of this factor versus satellite-derived sea surface temperature anomaly (SST anomaly: Reynolds and Smith, 1994: Fig. 8). The correlation coefficients were higher at Station SA $(r=0.83)$ than Station AB $(r=0.57)$, because of the differences in the foraminiferal faunal composition and the temperature in the upper layer. The temporal variation of foraminiferal faunal composition was usually lower at Station AB than Station SA throughout the observed period (Figs. 4g, 4h). The amplitude of SST anomaly and SST were higher at pelagic Station SA than hemipelagic Station $\mathrm{AB}$. The temporal variation of the SST anomaly at Station $\mathrm{AB}$ ranged from -1 to $+1{ }^{\circ} \mathrm{C}$ whereas that at Station SA ranged from -2 to $+1{ }^{\circ} \mathrm{C}$. Furthermore, the SST at Station SA was approximately $2^{\circ} \mathrm{C}$ higher than that at Station $\mathrm{AB}$ through most of the study period (Figs. $4 \mathrm{a}, 4 \mathrm{~b}$ ). The lower variation in the faunal composition is partially the reflection of the lower temperature variation at Station AB than Station SA. 
The factor scores showed high values during 1996 to 1997 at both stations. Even though the correlation coefficients of this factor with SST anomaly were low at Station AB, it is still reasonable to conclude that this factor represented temperature changes at both stations.

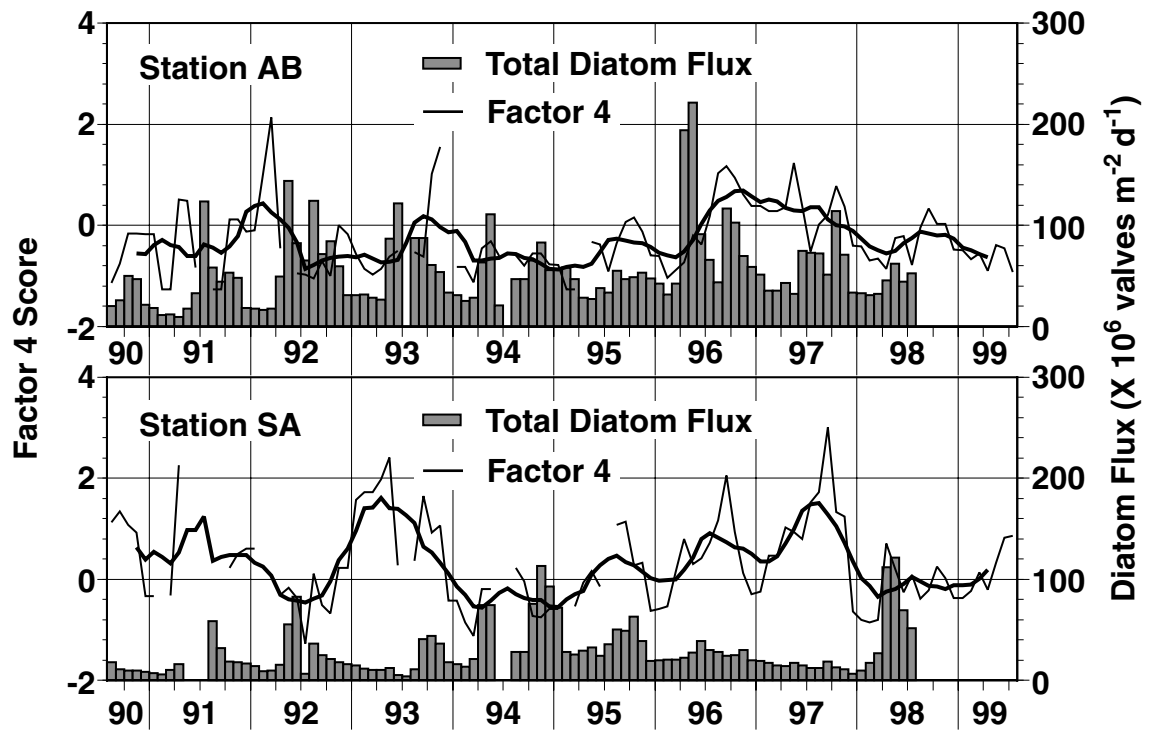

Fig. 8. The nine year-long time-series of total diatom fluxes (Takahashi et al., 2002) and Factor 4 (Oligotrophic Factor) during 1990 to 1999 at Stations AB and SA.

Among the other temperature-related factors, "Seasonal Factor" (Factor 2) is the factor with intriguing seasonal variation. This factor is explained by the two dominant taxa; Neogloboquadrina pachyderma, and Globigerina umbilicata, which were two of the most dominant taxa at both study stations. Neogloboquardina pachyderma is a well known species living in the subpolar to polar regions whereas $G$. umbilicata is known to live in the subarctic to transitional waters. Note that the name of the species $G$. umbilicata employed in our study was earlier regarded as Globigerina bulloides in the other sediment trap studies (Sauter and Thunell, 1989 and Kuroyanagi et al., 2002). Nevertheless, we distinguished $G$. umbilicata from G. bulloides by its thick shell wall and its texture (Ujiié and Ichikura, 1973) in our study; these two taxa were identical to the other sediment trap studies in the subarctic Pacific because of the indication by Ujiiè (2003). A significant feature of this factor is described by the conspicuous one yearlong cycle (Fig. 7). The factor score of "Seasonal Factor" tends to show its seasonal maxima during summer to fall season at both stations (Figs. 4k, 4l). This is ascribable because that the percent abundance of G. umbilicata increased during the warm periods (Asahi and Takahashi, 2007). With these, it is envisioned that this factor represents the seasonal variation of the foraminiferal faunal assemblages, which is mostly affected by the temperature change in the surface.

It is noteworthy to discuss about "Warm Water Factor" (Factor 1). Because that a significant increase of this factor at Station SA draws an attention as the most notable changes in the faunal composition occurred during the study period (Figs. 4i, 4j). The anomalous high factor scores were observed during 1996, 1997 at Station SA followed by a significant decrease in the Shanon-Wiener diversity index (Fig. 
4h). This intriguing event was only observed at Station SA. At the same time, an extremely low foraminifer flux was also observed (Figs. 4e, 4f).

This unique suppression was not only observed for foraminifers, but also for diatom and total mass fluxes (Takahashi et al., 2002). The factor loadings clearly exhibited that this factor was dominated by the warm water species such as Orbulina universa and Globorotalia wilesi. Extensive studies on O. universa showed that there was a general agreement that this taxon lived in warm to subtropical waters (e.g., Bè and Tolderlund, 1971; Thunell and Honjo, 1981). Moreover, a few appearances of this taxon were also reported by other sediment trap studies in the North Pacific (Sauter and Thunell, 1987; Kuroyanagi et al., 2002). While this unique increase of this "Warm Water Factor" was observed during 1997, the satelliteobserved SST was only $1^{\circ} \mathrm{C}$ higher than that of a typical year (Fig. 4d). Hence, this remarkable event was not only a clear evidence of the warm water effects to the faunal assemblages but also the reflection of the other anomalous oceanographic changes at Station SA.

There were several works reported on the climate change in the Pacific which can be linked to this event. Minobe (2000) reported that the sign of the regime shift were observed during this period in the northern Pacific and Alaska. In particular, the outstanding cool winter-spring air temperature was observed in Alaska during 1999. Moreover, this significant climate shift in the Pacific was discussed and described by the Pacific Decadal Oscillation Index (PDOI: Mantua et al., 1997). The time series examination of this index indicated the major shift of the climate system in the northern Pacific during 1999. These reports envisioned the possibility of occurrence of this significant climate shift in the northeastern Pacific. There have been several reports of the significant influence of this regime shift to the biological systems (e.g., Venrick et al., 1987; Roemich and McGowan, 1995; McGowan et al., 1998; Francis et al., 1998). In their studies, it was reported that a significant decrease in the plankton biomass in the northern Pacific was linked to this climatic shift.

It is envisioned that there is a link between the large scale climatic shift and the high values of "Warm Water Factor" associated with the significantly low biogenic particle flux (Takahashi et al., 2002). In other words, it is considered that the significant high value of "Warm Water Factor" at Station SA is one of the useful records of the major regime shift in this region. This noteworthy increase in "Warm Water Factor" is observed only at Station SA. Furthermore, the amplitude of "Warm Water Factor" is larger at Station SA than that at Station $\mathrm{AB}$. The trend in time series changes of this factor at Station $\mathrm{AB}$ is similar to the Shanon-Wiener diversity index and SST anomaly at the same station (Figs. 4c, 4g, 4k). This fact refers that "Warm Water Factor" at Station AB represented the temperature changes in the surface. Hence, it is thought that the effect of Pacific Decadal Oscillation was much more significantly represented at pelagic Station SA than at hemipelagic Station AB.

The other factor, which may have given influences in this intriguing event during 1997 at Station SA, is a change in the position of the Polar Front. Belkin et al. (2002) has mentioned that there is a significant oscillation pattern in the position of the Polar Front at $170^{\circ} \mathrm{E}$. In their study, the Position of Polar Front extended to northward from $42^{\circ} \mathrm{N}$ to $47^{\circ} \mathrm{N}$ during 1992 to 1997 . However, this notable moving of the Polar Front was only observed at $170^{\circ} \mathrm{E}$. This shift of the position of the Polar Front may bring warm waters via the Alaskan Stream to the Station SA.

The other interesting feature, which may explain this intriguing event during 1997, was the temporal variation of the biological domains. Gregr and Bodtker (2007) mentioned that there was a significant difference in the position of the biological domains between those during 1966 to 1975 and 1980 to 1989 in the North Pacific by using the image classification method to the General Circulation Model. They indicated that the change in the biological domains in the North Pacific was a reflection of the change in the regime during their study period. They also mentioned that the position of the Subarctic Current, which fluctuates seasonally between $50^{\circ} \mathrm{N}$ (summer) and $45^{\circ} \mathrm{N}$ (winter), had great impact on the biological domains. With the limited data we have obtained for this period, it is not possible for us to explain this anomalous event observed during 1997 at Station SA. Further investigations, including comparisons of 
physical oceanography and climatological data-sets, are warranted.

Besides the intriguing trend in the temperature-related varimax factors, it is notable to discuss about the factors linked to other oceanographic changes. The nine year-long time-series of "Oligotrophic Factor" (Factor 4) draws a notable attention when it is discussed with the local export production and the change in the surface circulation. The factor loading of this "Oligotrophic Factor" is dominated by Globigerina quinqueloba. The geographic distribution of this taxon is correlated to the local primary production in the subarctic Pacific (Asahi and Takahashi, 2007), when the means of diatom flux was compared to $\% G$. quinqueloba at four sediment trap study stations (Station PAPA: Sauter and Thunell, 1989; Station 50N: Kuroyanagi et al., 2002; Stations AB and SA: Asahi and Takahashi, 2007).

The nine year-long time-series values of this factor tend to show high values, when diatom fluxes at the same stations (Takahashi et al., 2002) were relatively low (Fig. 9). This relation appeared to be more conspicuous at Station SA than Station AB. Furthermore, the amplitude of this factor is greater at Station SA than that at Station AB. Although the trend of the diatom flux and "Oligotrophic Factor" is less significant at Station $\mathrm{AB}$ than Station $\mathrm{SA}$, we can conclude that the timing of the high factor scores and low diatom fluxes at Station AB is synchronous. Takahashi et al. (2000) illustrated that temporal fluxes of diatoms tended to become smaller when SST anomaly was positive at the same sediment trap stations. This is because that the relatively warm SST obstructed the seasonal mixing of the surface water with the subsurface water, which plays a large role in the nutrient supply to the upper layer. The correlation coefficient $r$ for the SST anomaly with "Oligotrophic Factor" is 0.62 at Station AB whereas that is 0.20 at Station SA. And thus, the temporal variation of SST is a controlling parameter of the local primary production in the Bering Sea (Station $\mathrm{AB}$ ) whereas the other oceanographic parameters might have played significant roles at Station SA.

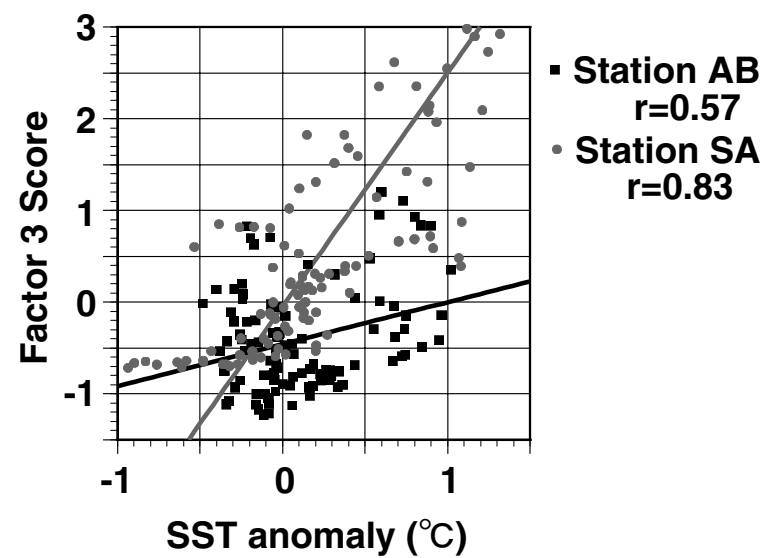

Fig. 9. The scatter plot of Factor 3 (Temperature Factor) vs. SST anomaly at Stations AB and SA.

This notable relation of "Oligotrophic Factor" and diatom fluxes can be described at Station SA, when we consider the surface circulation in this region. The variation of the water masses can be expected due to the transport by two significant surface currents: the Subarctic Current in the south of Station SA and the Alaskan Stream in the north. The former current is the eastward flow originating from the Western Subarctic Gyre whereas the later is the westward flow originating form the Gulf of Alaska. Physical oceanographic studies on these two currents revealed that the paths depending upon their strength varied 
intra-annually and inter-annually (Ohnishi and Ohtani, 1999; Ohnishi, 2000). Their studies reported that the annual water mass transport of the Subarctic Current during 1993 to 1996 dropped about one half level of that observed during 1990 to 1992 . And thus it is envisioned that the effect derived by the Alaskan Stream was relatively strong during 1993 to1996, compared to that during 1990 to 1992.

We examined the effect of the Alaskan Stream by comparing foraminiferal assemblages at Station SA to the other sediment trap studies along the $49^{\circ} \mathrm{N}$ line (Station PAPA: Sauter and Thunell, 1987; 50N: Kuroyanagi et al., 2002; Asahi and Takahashi, 2007). The foraminiferal faunal assemblage during this period was similar to that at Station PAPA in the Gulf of Alaska. This result indicated a strong influence by the Alaskan Stream during 1997. There is a general agreement of an increasing trend of biological production from the east (Gulf of Alaska) to the west (off Kamchatska) (see Takahashi et al., 2000). Keeping this in mind, a significantly high "Oligotrophic Factor" and low diatom flux during 1996 to 1997 at Station SA were the evidence of the relatively strong effect by the Alaskan Stream, originated from the Gulf of Alaska. There has been a report showing a causal relationship between diatom fluxes and the correlation of the diatom flux with the surface water circulation as well as the density of the upper water masses in the Gulf of the Alaska (Takahashi et al., 1990). And thus it is concluded that the water mass transport of the Alaskan Stream partially affected the temporal variation of the diatom fluxes at Station SA whereas the temperature variation affected to the temporal variation of the diatom fluxes at Station $\mathrm{AB}$.

\subsubsection{Periodicity of foraminiferal flux and its faunal assemblages}

It is notable to discuss the periodicity of the foraminiferal flux and its faunal assemblages, when we consider their temporal variations. For the foraminifer flux, there are significant cycles observed; six month, twelve month, and twenty to forty month-long cycles for the most of foraminiferal taxa except for Orbulina universa and Globorotalia wilesi (Fig. 5). Their abundances usually ranged less than $0.1 \%$ except for 1997 when their abundances reached $60 \%$ as the maximum. Therefore, the periodicity of these two taxa appeared more likely to be annual.

The other four taxa, which appeared to have conspicuous inter-annual and intra-annual cycles, draw an attractive attention to discuss their periodicity. Among the cycles described, six month and twelve monthlong cycles are characterized as the seasonal variation of their fluxes. These seasonal cycles are referred to two significant seasonal flux maxima; one in fall (September to December), and the other in spring (April to June). These two significant cycles are referred to the primary flux maxima observed in fall at Station $\mathrm{AB}$ and in spring at Station $\mathrm{SA}$, which were higher than the secondary flux maxima appeared in spring at Station AB and in fall at Station SA (Asahi and Takahashi, 2007).

These cycles are conspicuously observed for the most of the foraminiferal taxa. However, the amplitudes of the power spectrum are different by each taxon; Neogloboquadrina pachyderma and Globigerinita glutinata with relatively strong six month-long cycle, and Globigerina umbilicata and Globigerina quinqueloba with relatively strong twelve month-long cycle. The nine year-long monthly mean fluxes of each of the foraminiferal taxa clearly represented this trend. The former taxa tended to have bimodal flux maxima within a year, whereas the latter one appeared to have a single flux maximum. It is interesting that these two taxa with a single annual flux maximum tended to be present in fall season at Station SA (Asahi and Takahashi, 2007). This fact represents a possible occurrence of the seasonal segregation of these four foraminiferal taxa. In detail, G. quinqueloba and G. umbilicata preferred relatively warm environment in the subarctic condition.

Besides discussing the periodicity of foraminifer fluxes, it is worthy to discuss the periodicity of percent abundances of each foraminiferal taxon, when we consider their seasonal variation. For the foraminiferal faunal assemblages, there are significant periodicity observed; six month, twelve month and twenty to forty month-long cycles (Fig. 6). Among these cycles, significant twelve month-long cycle of Globigerina umbilicata and Globigerinita glutinata draw an attention. These two taxa showed significant twelve month-long cycles of their fluxes as described in the previous section. 
The percent abundance of G. glutinata tended to have their maxima during winter season. This is because that it was the only the taxon whose flux maxima appeared in winter, when the other foraminifer flux reached their minima at Stations AB and SA (Asahi and Takahashi, 2007). Despite of this taxon's apparent seasonal variation in winter, its percent abundance tended to increase significantly in the periods when SST anomaly was positive (Asahi and Takahashi, 2007). Therefore, it is envisioned that this taxon preferred the relatively warm winter.

The percent abundances of G. umbilicata appeared to have its maxima during summer to fall season at Stations $\mathrm{AB}$ and SA. There is a general understanding that $G$. bulloides, which is an identical taxon to $G$. umbilicata in our study, prefers the upwelling condition (e.g., Thunell and Reynolds, 1984). However, the nine year long monthly means of its relative abundance at Stations AB and SA went against this preference described by other studies. This taxon is known as subpolar to transitional species besides their preference in upwelling condition. Keeping this in mind, it is envisioned that the percent abundances of this taxon is controlled by the combination of these two oceanographic features. In other words, this taxon was more influenced by the temporal variation of the SST than the upwelling condition at study stations.

Besides these taxa whose seasonal variation are significant, the periodicity of the percent abundances of Globigerina quinqueloba is of great interest to discuss. The MEM power spectrum of this taxon is apparent in twelve month and twenty to forty month-long cycles. In a previous section, it was discussed that G. quinqueloba prefered the condition with a relatively low local primary production in the subarctic conditions. Furthermore, the nine year monthly means of its percent abundance tended to increase in a warm period, when the surface water was well stratified by the warm surface water (Asahi and Takahashi, 2007). Considering the information described for this taxon, it is believed that the possible occurrence of the annual variations in some oceanographic features controlled the local primary production at the study stations.

The periodicity of R-mode true factors showed apparent inter-annual cycles (Fig. 7). All of four factors appeared to show their MEM spectrum maxima in twelve month and twenty to forty month-long cycles. This refers that the temporal variation of the whole foraminiferal faunal assemblages varied inter-annually, whereas each of its abundance showed their seasonal variations. Among these factors, "Seasonal Factor" appeared to have a significant twelve month-long cycle. This factor tends to be high during summer, and thus it represents the seasonal variation of foraminiferal assemblages.

The other factors show significant inter-annual cycles. A significant inter-annual periodicity is clearly visible for "Warm Water Factor" at Stations AB and SA. As described in the previous section, this factor is dominated by Orbulina universa and Globorotalia wilesi, which are considered as tropical to transitional species. A period with significantly high scores of this factor is apparent during 1996 and 1997 only at Station SA. However, the MEM power spectrum of this factor represents a significant forty month-long cycle at both stations. This refers that the same oceanographic features occurred at Station SA affected the faunal assemblages at Station $\mathrm{AB}$, although the amplitude of the factors was insignificant. In other word, this unusual event during 1997 occurred at both Station AB and Station SA. However, the impacts to the biological system at Station $\mathrm{AB}$ during this period was less significant than these at Station SA. It is assumed that intra-annual variation of these factors is coincidental with the inter-annual large scale climatic changes. In the study region, there have been several studies on the temporal variation of climatic features. Mcfarlane et al. (2000) introduced a composite index (the Atmospheric Forcing Index: AFI) based on three aspects of climate ocean conditions known in the Pacific: the Aleutian Low Pressure Index (ALPI: Beamish et al., 1997), the Pacific Circulation Index (PCI: King et al., 1998), the Pacific Interdecadal Oscillation Index (PDO: Mantua et al., 1997). These studies revealed inter-annual oscillation of these climatic indices. The annual means of the AFI showed that the intensity and the position of the Aleutian Low Pressure varied their strength every other year during 1990 to 1999 (Beamish et al., 1997). And thus, it is reasonable to accept that the large scale climatic change affected the faunal composition at Stations $\mathrm{AB}$ and SA. 


\section{Conclusions}

The statistical and mathematical calculations have been performed to understand the temporal variation and the periodicity of the long-term time-series foraminifer fluxes in the Bering Sea and the central subarctic Pacific. The varimax factor analysis to the faunal assemblages presented four factors. The faunal information to the factor loadings revealed that first three factors reflected variations in the surface temperature.

Significantly high factor scores of "Warm Water Factor" are observed during 1997 to 1998 at Station SA. This significant feature is a consequence of the large scale climatic change such as the intensification of the Aleutian Low Pressure. The power spectrum of this factor indicates that such unusual large scale climatic shift brought biological impacts at both stations. However, their influence upon the biological systems in the Bering Sea was smaller than that in the central subarctic Pacific.

The second factor "Seasonal Factor" is dominated by Globigerina umbilicata. A twelve month-long is clearly visible for this factor. This refers that this factor represented seasonal variations of the foraminiferal assemblages at Stations $\mathrm{AB}$ and $\mathrm{SA}$.

Third factor "Temperature Factor" clearly exhibited a correlation with the SST anomaly. This factor is dominated by Globigerinita glutinata. While the seasonal variation of this taxon showed a significant increase in their relative abundances during winter, the correlation coefficient $r$ for this factor and SST anomaly showed a reasonable correlation (Station AB: 0.57; Station SA: $r=0.83$ ).

The forth factor "Oligotrophic Factor" is dominated by Globigerina quinqueloba. The geographic distribution of this taxon in the subarctic Pacific and the Bering Sea clearly shows that the taxon prefers the environment with relatively low biological production. The temporal variation of this "Oligotrophic Factor" coincides with the SST anomaly at hemipelagic Station AB, where it showed a reasonable correlation with the temporal variation in strength of the Alaskan Stream at pelagic Station SA. This indicates a different condition which affected the local primary production in the study region. The temperature condition in the upper layer, which regulates the subsurface nutrient supply to the surface, is pointed out as a controlling factor of the local primary production at Station AB. On the other hand, the surface circulation described as the power balance of the Alaskan Stream and the Subarctic Current wass the controlling factor at Station SA. These intriguing pieces of information derived by foraminiferal faunal assemblages tends to have an inter-annual periodicity, which have possible consequences with the large scale climatic shift such as the Pacific Decadal Oscillation and the variation of the Aleutian Low Pressure.

The periodicity of foraminifer flux and its faunal assemblages clearly represented their seasonal and annual variations. Most foraminifer taxa tended to have their primary flux maxima during fall (Station $\mathrm{AB}$ ) and spring (Station SA) followed by secondary maxima in spring (Station $\mathrm{AB}$ ) and fall (Station $\mathrm{SA}$ ). Neogloboquadrina pachyderma and Globigerina quinqueloba were the two taxa which followed this periodicity significantly.

The other two taxa, represented by Globigerina umbilicata and Globigerinita glutinata, appeared to demonstrate a twelve month-long periodicity for their fluxes. Their percent abundances also exhibited significant twelve month-long periodicity. The nine year-long monthly means of their flux and percent abundances indicated their preference of a specific condition. The flux and the percent abundance of Globigerina umbilicata tended to increase in a warm condition during fall, whereas these of Globigerina glutinata appeared to be present in a relatively warm winter. The periodicity of the R-mode true factor is clearly visible inter-annually, while the periodicity of the percent abundances of the most foraminifer taxa expressed the seasonal variation. This fact indicates that the temporal succession of foraminiferal faunal assemblage in the study region is more likely to represent seasonal variation than the large scale climate shift when we only discuss short term variation of the faunal assemblages. In other words, the long-term observation of the biological successions has a key to achieve general understandings of large scale climatic shift occurred in the study region. 
Our study clearly represented the inter-annual variation of the foraminiferal faunal assemblages along with the oceanographic changes. The results of true factor analysis exhibited twenty to forty month-long cycles of their variation in the faunal assemblages. These intra-annual variation in their faunal assemblages was the reflection of the large scale climatic shift occurred in the Bering Sea and the central subarctic Pacific.

\section{Acknowledgements}

The authors gratefully acknowledge the captains, officers, crew, scientists, and students who assisted in sediment trap deployments/recoveries on board T/S Oshoro-Maru, Hokkaido University, which took place in 1989-1999. We thank a number of scientists and graduate students who contributed to this work. In particular, we acknowledge Prof. Mitsuru Yanada at Graduate School of Fisheries of Hokkaido University and Mr. Naoki Fujitani at Graduate School of Sciences of the Kyushu University, for corporation in the sediment trap experiment. Our thanks are extended to Dr. Hiroshi Nishi at Graduate School of Social and Cultural Studies at the Kyushu University for providing taxonomic instruction to HA on foraminifers and useful advise. A draft manuscript of this paper has been critically reviewed by Dr. Yusuke Okazaki of JAMSTEC, which prompted to improve this paper.

The senior author (HA) received a partial funding supports from Tatsuro Matsumoto Scholarship and the Nippon Foundation-HADal Environmental Science Education Program (HADEEP) to this study. This work was partially supported by the following research programs to the junior author (KT): MEXT Grantsin-Aid-for Scientific Research B2 Project No. 15310001 and JSPS B Project No. 17310009.

\section{References}

Asahi, H., and Takahashi, K. (2007) A 9-year time-series of planktonic foraminifer fluxes and environmental change in the Bering sea and the central subarctic Pacific Ocean, 1990-1999. Progress in Oceanography, 72, 343-363.

Bé, A.W.H., and Tolderlund, O.L. (1971) Distribution and ecology of living planktonic foraminifera in surface waters of the Atlantic and Indian Oceans. In Funnell, B.M., and Riedel, W.R. (ed.) Micropaleontology of Oceans, Cambridge University Press, London, 105-149.

Belkin I., Krishield, R., and Honjo, S. (2002) Decadal variability of the North Pacific Polar Front: Subsurface warming versus surface cooling. Geophysical Research Letters, 29 (9), 1351, doi: 10.1029/2001GL0138062002.

Beamish, R.J., Neville, C.E., and Cass, A.J. (1997) Production of Fraser River sokeye salmon (Oncorhynchus nerka) in relation to decadal-scale changes in the climate and the ocean. Canadian Journal of Marine Sciences, 54, 1200-1215.

Bijma J., Faber W.W., and Hemleben C. (1990) Temperature and salinity limits for growth and survival of some planktonic foraminifers in laboratory cultures. Journal of foraminiferal research, 20(2), 95-116.

Bradshaw, J.S. (1959) Ecology of living planktonic foraminifera in the north and equatorial Pacific Ocean. Journal of Foraminiferal Research, 10, 25-64.

Burg, J.P. (1967) Maximum entropy spectrum analysis. $37^{\text {th }}$ Ann. Int. Meet. Soc. Explor. Geophys. Oklahoma City, OK.

Carstens, J., Hebbeln, D., and Wefer, G. (1997) Dstribution of planktic foraminifera at the ice margin in the Arctic (Fram Strait). Marine Micropaleotology, 29(3-4), 257-269.

Costello, A.B., and Osbourne, J.W. (2005) Best practices in exploratory factor analysis: Four 
recommendations for getting the most from your analysis. Practical Assesment, research and Evaluation, 10(7). Available online:

http://pareonline.net/getvn.asp?v=10\&n=7

Dodimead, A.J. (1967) Winter oceanographic conditions in the central Subarctic Pacific. Int. North Pacific Comm., Doc 999, 14.

Dodimead A.J., and Pickard G.L. (1976) Annual changes in the oceanic-coastal waters of the eastern Subarctic Pacific. Journal of Fishery Research Board of Canada, 24, 2207-2227.

Donner, B., and Wefer, G. (1994) Flux and stable isotope composition of Neogloboquadrina pachyderma and other planktonic foraminifers in the Southern Ocean (Atlantic Sector). Deep Sea Research I, 41, 1733-1743.

Eguchi, N.O., Kawahata, H., and Taira, A. (1999) Seasonal response of planktonic foraminifera to the ocean surface condition: sediment trap results from the northcentral Pacific Ocean. Journal of Oceanography, 55, 681-691.

Eguchi, N. O., Ujiié, H., Kawahata, H., and Taira, A. (2003) Seasonal variations in planktonic foraminifera at three sediment traps in the Subarctic, Transition and Subtropical zones of the central North Pacific Ocean. Marine Micropaleontology, 48, 149-163.

Francis, R.C., Hare, S.R., Hollowed, A.B., and Wooster, W.S. (1998) Effects of interdecadal climate variability on the oceanic ecosystems of the NE Pacific. Fisheries Oceanography 7 (1), 1-21.

Gregr, E.J., and Bodtker, K.M. (2007) Adaptive classification of marine ecosystems: Identifying biologically meaningful regions in the marine environment. Deep Sea Research I, 54, 385-402.

Harrison P.J., Whitney, F.A., Tsuda, A., Saito, H., and Tadokoro, K. (2004) Nutrient and Plankton Dynamics in the NE and NW Gyres of the Subarctic Pacific. Journal of Oceanography, 60(1), 93-117.

Hemleben, C., Spindler, M., and Anderson, O.R. (1989) Modern Planktonic Foraminifera, Springer, New York, 363pp.

Honjo, S., and Doherty, K.W. (1988) Large aperture time-series sediment traps: design objectives, construction and application. Deep Sea Research, 35, 53-97.

Imbrie, J., and Kipp, N.G. (1971) A new micropaleontological method for quantitative paleoclimatology: Application to a late Pleistocene Caribbean core. In Tureloam, K., K. (ed.), The late Cenozoic glacial ages, New Heaven, Yale University Press, 71-181.

Kincaid, E., Thunell, R.C., Lange, J.L.B., Weinheimer, A.L., and Reid, F.M.H. (2000) Planktonic foraminiferal fluxes in the Santa Barbara Basin: response to seasonal and interannual hydrographic changes. Deep-Sea Research II, 47, 1157-1176.

King, J.R., Ivanov, V.V., Kurashov, V.,Breamish, R.J., and. MaFarlane, G.A. (1998) General circulation of the atmosphere over the North Pacific and its relationship to the Aleutian Low. North Pacific Anadromous Fish Commission Doc. No. 318. Fisheries and Oceans Canada, Pacific Biological Station, Nanaimo, BC, Canada, V9R 5K6. Arctic and Atlantic Research Institute, 38 Bering Street, St. Petersburg, Russia, 199397, 18pp

King, A.L. and Howard, W.R. (2003) Planktonic foraminiferal flux seasonality in Subarctic sediment traps: A test for paleoclimate reconstructions. Plaeoceanography, 18, 1019, doi: 1010.1029/2002PA000839.

Kipp, N.G. (1976) New transfer function for estimating past sea-surface conditions from sea-bed distribution of planktonic foraminiferal assemblages in the North Atlantic. Geological Society of America Memoir, 145, 3-41.

Kohfeld, K.E., Faribanks, R.G., Smith, S.L., and Walsh I.D. (1996) Neogloboquadrina pachyderma (sinistral coiling) as paleoceanographic tracers in polar oceans: Evidence from Northeast Water Polyna plankton tows, sediment traps, and surface sediments. Paleoceanography, 11, 679-699.

Kuroyanagi, A., Kawahata, H., Nishi, H., and Honda, C.M. (2002) Seasonal changes in planktonic 
foraminifera in the northwestern North Pacific Ocean: sediment trap experiments from subarctic and subtropical gyres. Deep Sea Research II, 49, 5627-5645

Levitus, S., and Boyer T. (1994) World Ocean Atlas 1994 Volume 4: Temperature, NOAA Atlas NESDIS 4, U.S. Department of Commerce, Washington D.C.

Mantua, N.J., Hare, S.R., Zhang, Y., Wallace, J.M., and Francis, R.C. (1997) A Pacific interdecadal climate oscillation with impacts on salmon production. Journal of the America Meteorological Society, 78, 1069-1079.

McFarlane, G.A., King, J.R. and Beamish, R.J. (2000) Have there been recent changes in climate ? Ask the fish. Progress in Oceanography, 47, 147-169.

McGowan, J.A., Cayan, D.R., and Dorman, L.M. (1998) Climate-ocean variability and ecosystem response in the Northeast Pacific. Science, 281, 210-217

Minobe, S. (2000) Spatio-temporal structure of the pentadecadal variability over the North Pacific, Progress in Oceanography, 47, 381-408.

Murray, J. (1897) On the distribution of the pelagic foraminifera at the surface and on the floor of the ocean. Natinal Science (Ecology), 11, 17-27.

Nagata, Y., Ohtani, K., and Kashiwai M. (1992) Subarctic Gyre in the North Pacific Ocean. Umi no Kenkyu, 1(3), 75-104 (In Japanese)

Ohnishi, H. (2001) Spatial and Temporal Variability in a Vertical Section across the Alaskan Stream and Subarctic Current. Journal of Oceanography 57, 79-91.

Ohnishi, H., and Ohtani K. (1999) On Seasonal and Year to Year Variation in Flow of the Alaskan Stream in the Central North Pacific. Journal of Oceanography, 55, 597-608.

Paillard, D., Labeyrie, L., and Yiou, P. (1996) Macintosh program performs time-series analysis, Eos Trans., AGU, 77, 379.

Reyment, R., and J?reskog, J.K. (1993) Applied Factor Analysis in the Natural Sciences. Cambridge Press, Cambridge U.K. 371 pp.

Reynolds, R.W., and Smith, T.M. (1994) Improved global sea surface temperature analysis. Journal of Climate, 7, 929-948.

Roemmich, D., and McGowan, J. (1995) Climatic warming and the decline of zooplankton in the California Current. Science, 267, 1324-1326.

Sauter, L.R., and Thenell, R.C. (1989) Seasonal Succession of Planktonic Foraminifera: results from a four-year time-series sediment trap experiment in the northeaset Pacific. Journal of Foraminiferal Research, 19, 253-267.

Schiebel R., Waniek, J., Brook, and M., Hemleben, C. (2001) Planktonic foraminiferal production stimulated by chlorophyll redistribution and entrainment of nutrients. Deep Sea Research I, 48, 721-740.

Schröder-Ritzrau A., Andruleit, H., Jensen S., Samtleben C., Schäfer P., Matthiessen J., Hass, H.C., Kohly A., and Thiede J. (2001) Distribution, export and alternation of fossilizable plankton in the Nordic Seas, In P. Schäfer, W. Ritzrau, M. Schlüter, and J. Thiede (ed.) The Northern North Atlanic: A changing Environment, Springer, Berlin, 81-104.

Takahashi, K. (1998) The Bering Sea and Okhotsk Sea: modern and past paleoceanographyc changes and gateway impact. Journal of Asian Earth Sciences, 16, 49-58.

Takahashi, K. (1999) Plaleocenographic changes and present environment of the Bering Sea, In P.R. Loughkin and K. Ohtani (ed.) Dynamics of the Bering Sea, University of Alaska Sea Grant, Fairbanks, Alaska, 365-385.

Takahashi, K., Billings, J.D., and Morgan J.K. (1990) Oceanic Province: assesment from the timeseries diatoms production in the northeastern Pacific. Limnology of Oceanography, 35 (1), 154165.

Takahashi, K., Fujitani, N., and Yanada, M. (2002) Long term monitorng of particle fluxes in the 
Bering Sea and the central subarctic Pacific Ocean, 1990-2000. Progress in Oceanography, 55, 95-112.

Takahashi, K., Fujitani, N., Yanada, M., and Maita, Y. (2000) Long-term biogenic particle fluxes in the Bering Sea and the central subarctic Pacific Ocean, 1990-1995. Deep Sea Research I, 47, 1723-1759.

Thunell, R.C., and Honjo, S. (1981) Calcite dissolution and the modification of planktonic foraminiferal assemblages. Marine Micropaleontology, 6, 169-182.

Thunell, R.C., and Reynolds, L.A. (1984) Sedimentation of planktonic foraminifera: seasonal changes in species flux in the Panama Basin. Micropaleontology, 30, 241-260.

Ujiie, H. (2003) A 370-ka paleoceanographic record from the Hess Rise, central North Pacific Ocean, and an indistinct 'Kuroshio Extension', Marine Micropaleontology, 49, 21-47.

Ujiié, H., and Ichikura, M. (1973) Holocene to uppermost Pleistocene planktonic foraminifers in a piston core from off San'in district, Sea of Japan. Transactions and Proceedings of Paleontological Society of Japan, N.S., 91, 137-150.

Venrick, E.L., McGowan, J.A., Cayan, D.R., and Hayward, T.L. (1987) Climate and chlorophylla: Long-term trends in the central North Pacific Ocean. Science, 238, 70-72.

Zaric S., Schulz, M., and Mulitza S. (2006) Global prediction of planktonic foraminiferal fluxes from hydrographic and productivity data. Biogeosciences, 3, 187-207. 


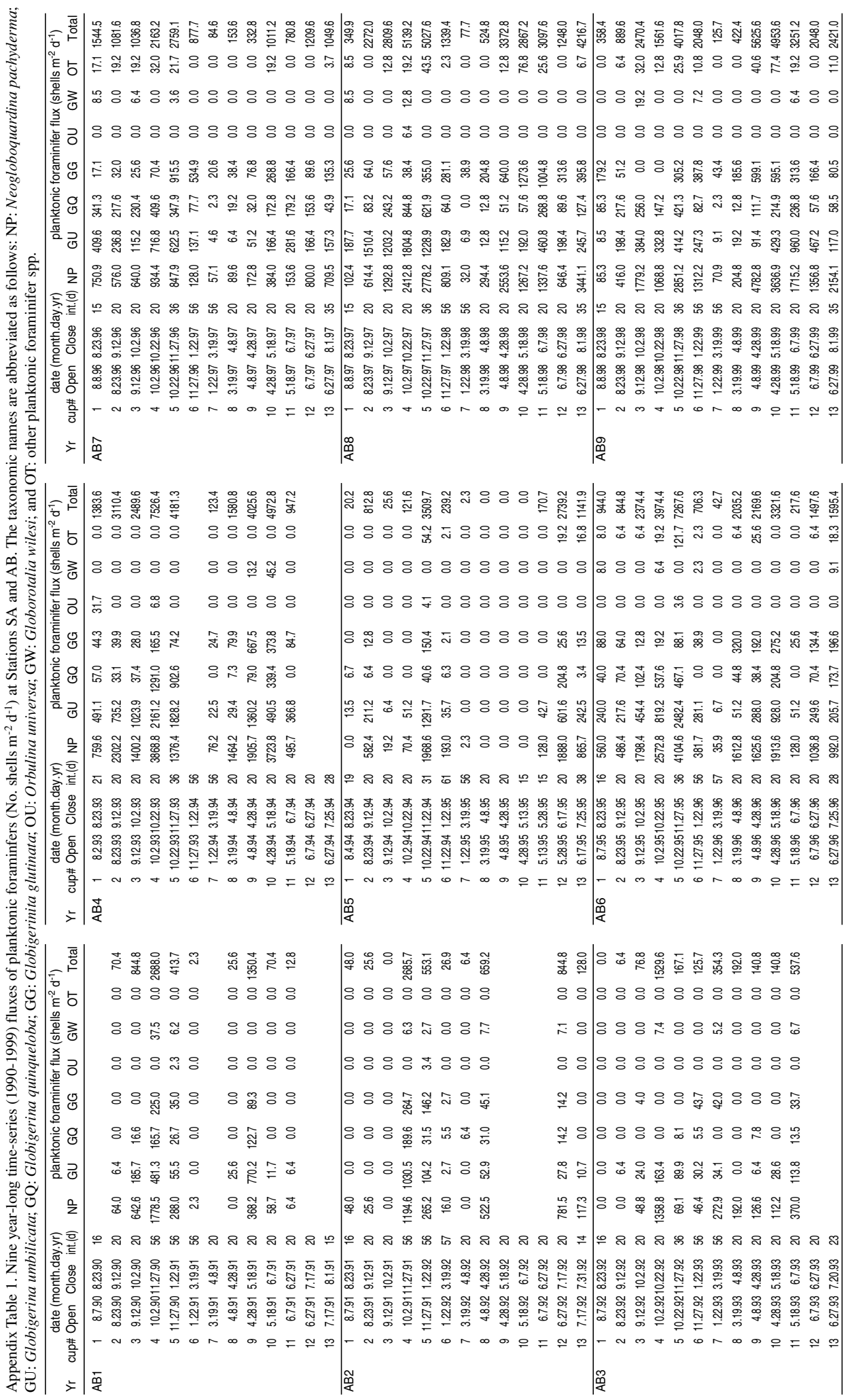




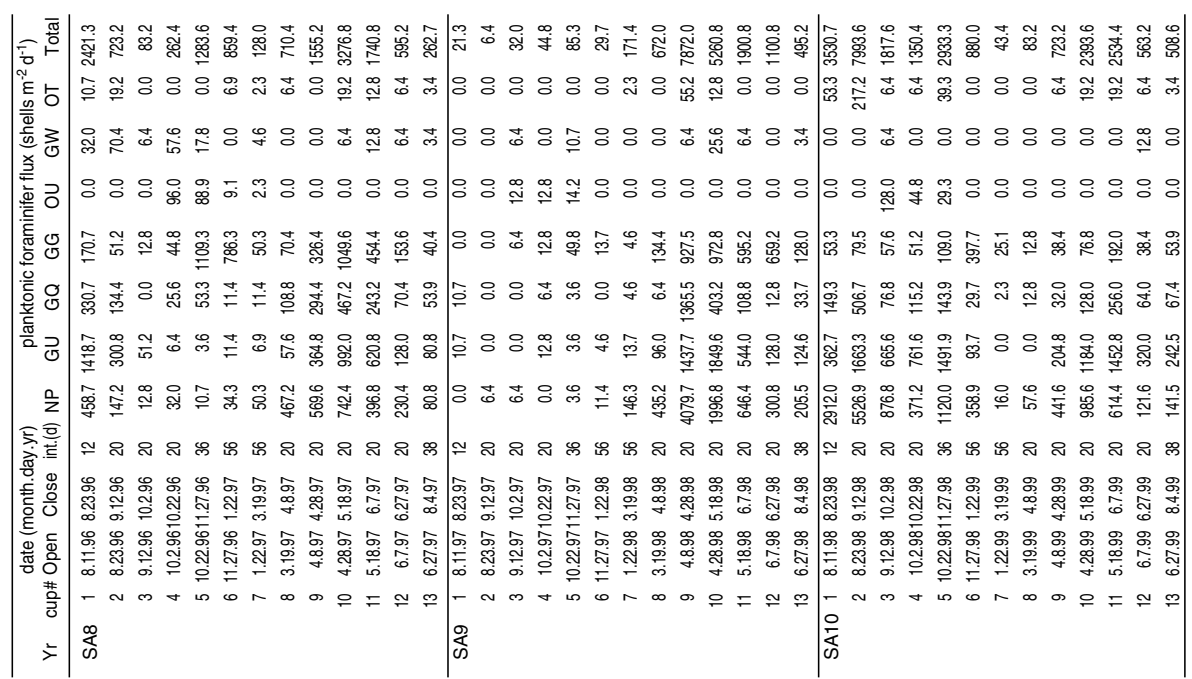

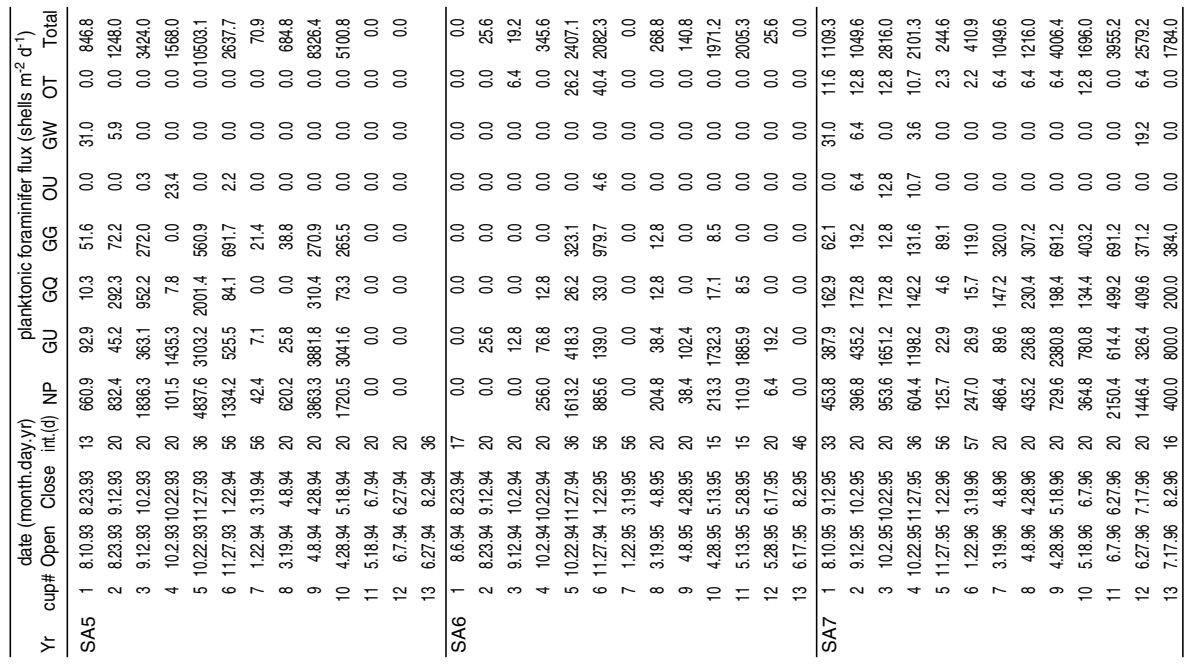

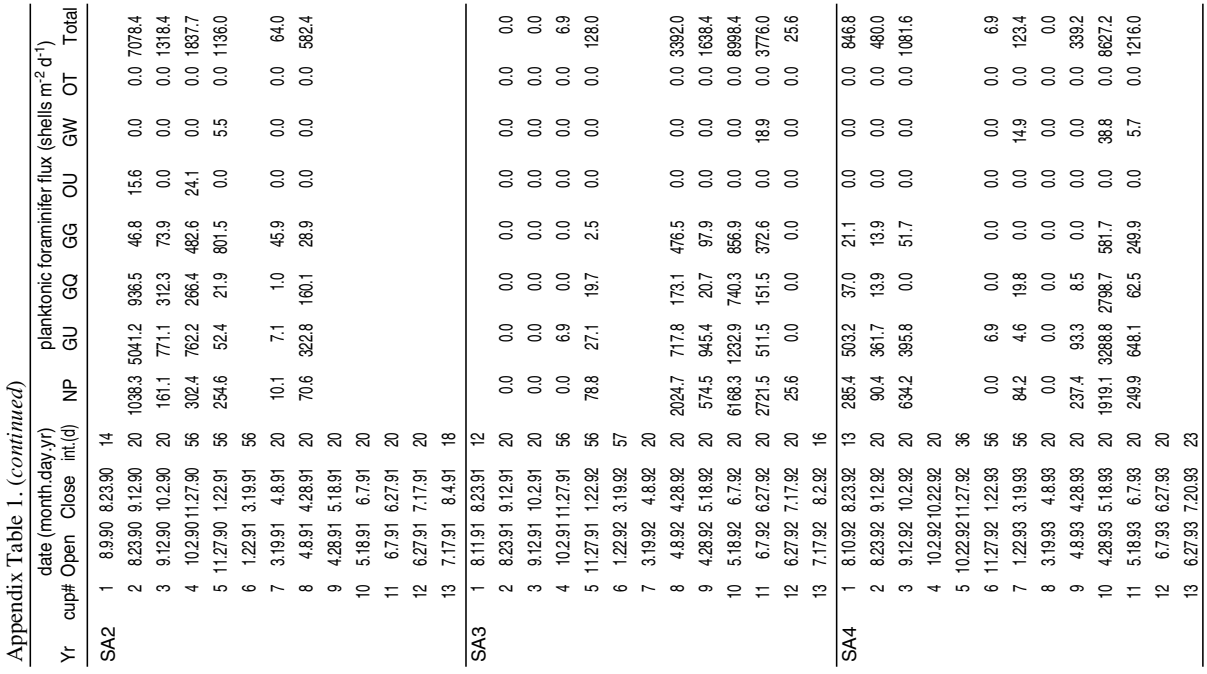

